\title{
Evaluation of Social and Economic Efficiency of Investments in Public Utility Services
}

\author{
Tatiana Jurievna Kudryavtseva ${ }^{1}$ \& Juriy Jurievich Kuporov ${ }^{1}$ \\ ${ }^{1}$ Peter the Great Saint-Petersburg Polytechnic University, Russian Federation \\ Correspondence: Tatiana Jurievna Kudryavtseva, Polytechnicheskaya street 29, St.Petersburg, 195251, Russian \\ Federation. E-mail: tankud28@mail.ru
}

Received: January 13, 2015 Accepted: April 30, 2015 Online Published: July 30, 2015

doi:10.5539/ass.v11n19p151 URL: http://dx.doi.org/10.5539/ass.v11n19p151

\begin{abstract}
This article substantiates theoretical approaches to evaluating the efficiency of investment projects in the field of public utility services, taking into account all elements of the system for public utility service delivery. The proposed methodology is based on the calculation of social, economic, and budgetary efficiency of the investments. Calculation of social efficiency is based on accounting lower prices as a result of cost savings arising due to the investments, and improving the quality of services. Calculation of budget efficiency savings assumes the costs of public utility services provision over the budgetary investments to economic efficiency of public utility services. The developed method has been tested at a Ukrainian public utility company.
\end{abstract}

Keywords: investments in public utility services, economic efficiency, social efficiency, budget efficiency, public utility company, Ukraine

\section{Introduction}

The relevance of the theme chosen for the study can be explained by the fact that currently assurance of economic growth is necessary to achieve significant gains in efficiency of the organization's management and to increase the efficiency of its economic activity. It is necessary to consider that the enterprises dealing with public utility services operate within a particular economic sphere created by the government, and the social significance of public services, which also requires taking into account the efficiency of consumer services.

Formerly the authors examined these issues from different sides: economic security, risk management, training, and improvement of the budget expenditure efficiency (Bakhmutskaya \& Kudryavtseva, 2010, pp. 137-146; Demidenko, Babkin, \& Kudryavtseva, 2010, pp. 204-208; Kuporov, 2014a, pp. 133-138; Kuporov, 2014 b, pp. 133-139; Rodionov, Rudskaia, \& Guzikova, 2014, pp. 215-223; Zaborovskaia, Plotnikova, \& Sharafanova, 2014, pp. 267-274).

Considering the organization's system of public services delivery, it is necessary to consider the objectives and actions of each of its elements (Bagel, Lukin, Shashkov, Chuvilin, \& Sharipov, 2012):

- Direct provider;

- End-users;

- Local authorities.

A service provider is considered to be the main subject in the system of public services generation (Figure 1). Economic behaviour of enterprises causes the response of other participants in the system. Consumers purchasing services meet their needs fully or partially, depending on the level of their ability to pay, the amount and quality of services provided. Local governments perform their functions on the implementation of their mandates. They compensate the company its costs incurred, called subsidies, and provide grants for public if the level of income does not allow the consumer to acquire the necessary volume of services. With the necessary credentials, local authorities set rates for basic services in order to protect consumers from the increase of services' cost by enterprises. Such an approach allows showing the interdependence and interaction of subjects of public sector - elements of the delivery system and consumption of services (Figure 1). 


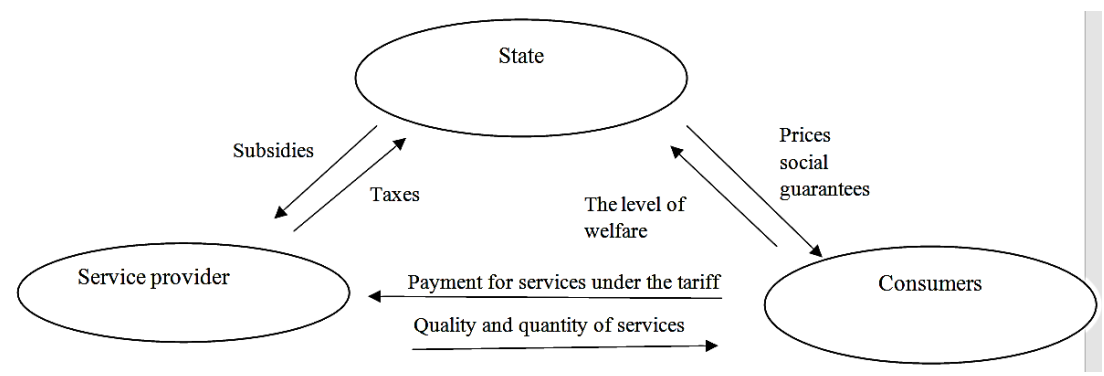

Figure 1. Interdependence and interaction of subjects of public sector - elements of the production system and consumption of services

Therefore, to determine the efficiency of the public services delivery within the presented model, it is necessary to conduct a comprehensive analysis of the efficiency, considering all elements of the utility service delivery system.

Under these conditions, determination of the system efficiency is reduced to calculation of three types of efficiency: economic, budgetary and social. Using solely the indicator of economic efficiency does not allow to judge on the efficiency of the model as a whole. High social importance of public services requires taking into account the service efficiency for consumers, and partial delivery of services at the expense of budget necessitates calculation of budget efficiency (Egorova, 2007, pp. 160-198).

Economic efficiency is considered as the efficiency for manufacturers, and it involves the assessment of the financial and operating activities of enterprises delivering public services. As a rule, difficulties in determining the economic efficiency do not arise due to the generally accepted methodology for assessing being used (Efimova, 2011; Sergeev, Veretennikova, \& Shekhovtsov, 2013).

Budget efficiency is the system efficiency from the perspective of local authorities, whose essential point of consideration is the fulfilment of obligations assigned in accordance with the law, which are executed to the full extent and under the lowest budgetary costs ("Government Decree", 2007). Within the system of public services delivery, budget efficiency shows the influence of the operating results of service providing companies on income and expenses of local budgets.

Social efficiency is the system efficiency estimation from the standpoint of consumers. Unambiguous definition of the concept of "social efficiency" does not exist, which causes certain problems in its defining. In broad terms, social efficiency is meeting the needs of the population.

Social efficiency, as well as the budget efficiency, is connected with the activity of a service providing enterprise. From this position, it represents social consequences of enterprise operation for population in general, which are expressed through the changes in life quality level. Social efficiency includes public significance and public usefulness of enterprise activity.

Public significance of enterprise activity represents social and economic consequences of enterprise activity for the population as a whole, including those defined by the percentage of population, which enjoys all the advantages achieved from the sale of products (goods, works, services) of the enterprise given. Public usefulness of enterprise activity is the degree of citizens willingness to benefit from the sale of products (goods, works, services) of an enterprise or organization, which is reflected in the creation of new products or in efficiency improvement of the already offered to population products, works and services, as well as in the economic development of the city, or enhancement of environmental conditions. Improvement of the goods, works and services efficiency shall be understood as the reduction in their costs and, as a consequence, decrease in rates, enhancement of their quality, assurance of their delivery continuity, expansion of the community having access to them.

Calculation of social efficiency can be represented as the ratio of the service volume obtained by a consumer to the expenditures on purchasing it. However, when calculating the social efficiency, one shall consider whose needs are being met by this or that service.

At individual consumption, personal interest works out for each consumer, who is interested in his or her needs being satisfied for a certain fee (Egorova, Mitrofanov, \& Shein, 2007, pp. 160-198). The consumer has an impact 
on the activities of a commercial entity while entering into a direct relationship with a manufacturer. Thus, social efficiency transforms into economic efficiency.

\section{Methodology. Methods of Assessing the Economic, Budgetary and Social Efficiency of Implementing Investment Programs Engaged in the Delivery of Public Goods}

It is found out that the main subject of the public services delivery system is an enterprise - a manufacturer of services, whose economic behaviour affects and causes responses of other system's participants.

Each of the system's subjects has its own requirements to the quality of services provided. On the one hand, the level of customer satisfaction is a key indicator of the efficiency of services delivery, because it can assess the level of services, i.e. social and economic indicators. On the other hand, manufacturers refer to the criterion of efficiency of technical and economic indicators.

The principle of economic efficiency shall not be the main principle and purpose of the public enterprises activity. However, increase in production efficiency can be achieved both by savings in operational costs, and by making better use of the existing capital. The most important factor in efficiency improvement is a scientific and technical progress. Computer-aided manufacturing, the widespread introduction of advanced technologies, the creation and use of new materials help to reduce labour and material costs, as well as to increase level of production. In addition, the production efficiency depends directly on the cost-cutting drive. Cost-effective use of resources shall become a crucial source for meeting the growing demands for fuel, energy and raw materials. Increase in production efficiency greatly depends on better use of fixed assets. Therefore, increase in production efficiency becomes possible through the implementation of activities under the enterprise's investment program (Oksogoev, 2014, pp. 327-330).

Evaluation of the project efficiency in general is necessary to determine the potential attractiveness of the project, the feasibility of its adoption. It shows the acceptability of an investment project objective from the economic efficiency point of view, depending on the financial capacity of its participants. In assessing the efficiency of the project as a whole, one shall take into account its social significance (social and economic efficiency), given the scale of the investment project. Economic, social and environmental consequences of the projects influence the whole society. That is why the efficiency of the whole project can be subdivided into two types: public (social and economic), which is necessary for the evaluation of socially significant projects; and commercial, which assessment is carried out in almost all the projects being implemented.

Public efficiency considers social and economic consequences of an investment project implementation for society as a whole, including, project's direct costs and results, as well as "external effects" - social, economic, and others (Demidenko, Babkin, \& Kudryavtseva, 2010, pp. 204-208).

Table 1 presents indicators of social, economic, and budgetary efficiency of an investment project in the field of public services. When calculating the economic efficiency of the project, the authors use the following theoretically substantiated and widely applied aggregate indicators - NPV, IRR, PI, and DPP.

In order to calculate the value of social efficiency, the authors offer to introduce additional components into the formula for calculating NPV, IRR, PI, and DPP, taking into account the cost savings of population as a result of the investment project implementation at the enterprise $\left(D_{n}\right)$ (Table 1). The cost savings of population may occur as a result of the following factors:

- Reduction in rates or prices for public services provided by enterprises as a result of improving technology and economies of production costs;

- Reduction in cost of service consumers as a result of improving the quality of services, such as uninterrupted, trouble-free, and timely delivery of services.

In the context of the public services delivery, it is assumed that the financing of such investment projects shall be carried out by local governments.

If thus calculated net present value of the project is positive ( $\mathrm{NPV}>0$ ), this means that in course of its economic life the investment project will reimburse the original budgetary costs of local governments, will provide the excess of discounted economic effects obtained as a result of saving production costs of a public enterprise and social cost savings of the population over the original budgetary expenditures.

Internal rate of return IRR represents such discount rate, at which the value of the given economic and social effects is equal to the given budgetary investments. Under these conditions, it is assumed that the discount rate shall be equal to the minimum value, i.e. risk-free rate of return, as all public services have social effects, which are qualitative in nature and cannot be transferred into monetary units. The value of IRR is compared with a 
predetermined discount rate $r$. Moreover, if the IRR $>r$, then the project provides a positive NPV. If IRR $<r$, then the budget costs exceed the economic and social effect measured.

Table 1. Indicators of social-economic and fiscal efficiency of the investment project in the field of public services

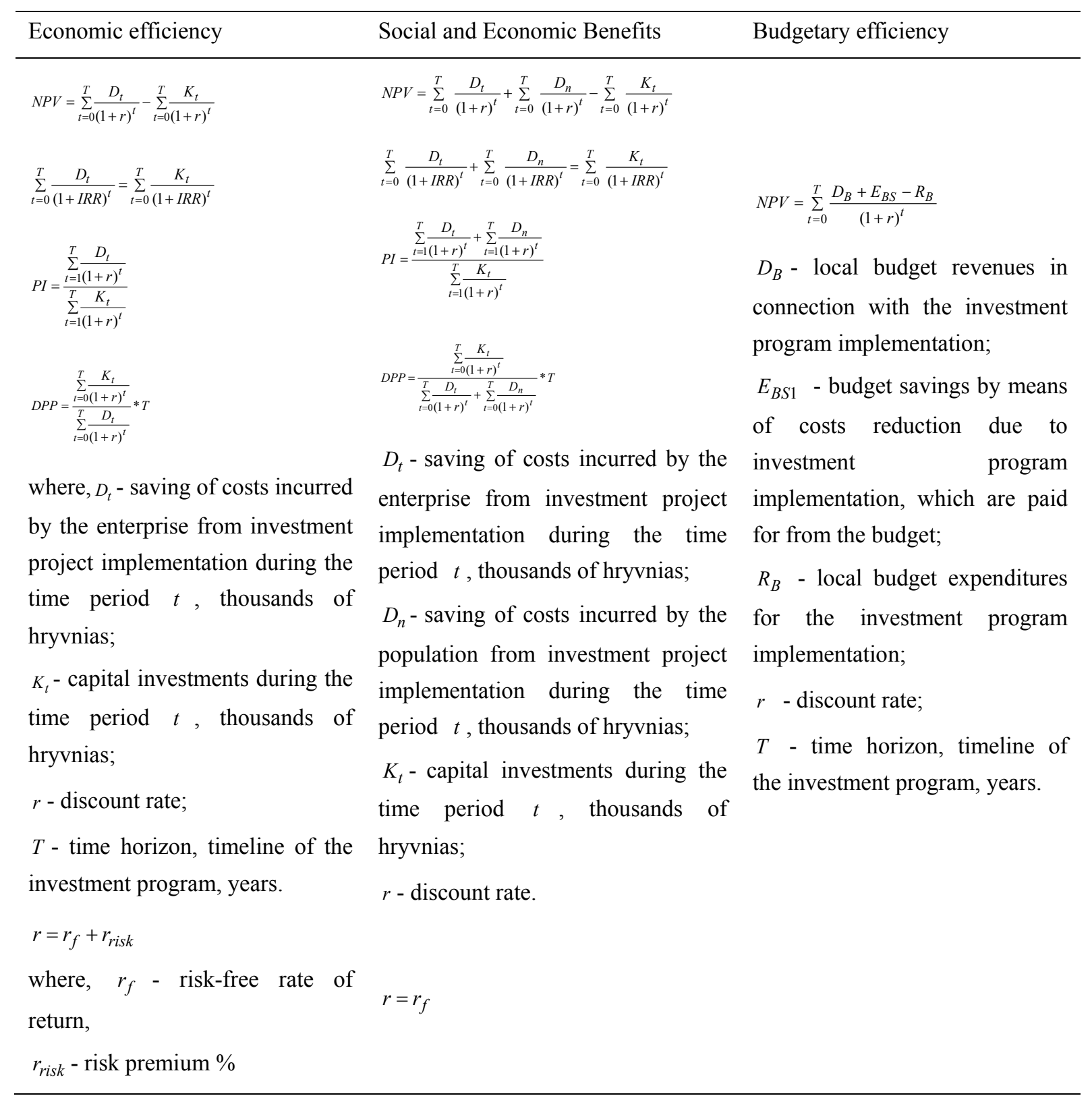

Profitability index (PI) shows the relative efficiency of the project or the discounted value of the total social and economic effects of the project, calculated using the unit of budgetary investment. If PI $>1$, the project is effective, i.e. production cost savings and social benefits of the project exceed the original budget investments, thereby ensuring the presence of the positive value of NPV.

Discounted payback period (DPP) is the minimum time interval from the start of the project implementation, beyond which the integral effect becomes and further remains non-negative. In other words, this is the period (measured in months, quarters or years), starting from which the original budgetary expenditures associated with the investment project are covered by the total savings of production costs and social effect. 
Determination of budgetary efficiency from the investment project implementation within the social sphere is performed by choosing from a feasibility study the investment project indicators included into the calculation of budgetary efficiency.

The NPV value when calculating the budgetary efficiency will demonstrate the increase of discounted budgetary revenues as a result of the enterprise's activity and the discounted economy of budgetary funds over the expenditures of the local budget for the implementation of the investment project (Table 1).

The additional tax and non-tax revenues in the regional (local) budget caused by the investment object usage are referred to as the incomes of the regional (local) budget related to the implementation of the project.

Factors of budgetary funds savings from the implementation of investment project can be as follows:

- Economy of budgetary funds due to decrease caused by the investment project implementation in the operating expenses paid from the state budget, public subsidies and subsidies to the enterprise;

- Economy of budgetary funds due to avoidance of possible expenditures of the regional (local) budget for the elimination of negative environmental and social impacts that may occur in the case of non-implementation of the investment project.

The difference between the operating costs of the local budget for the investment object exploitation prior to the implementation of the investment project and the expenses of the local budget after the start of the investment project implementation counted for five years can be considered as the economy of budgetary funds due to decrease in operating costs.

Possible expenditures can be considered as the economy of budgetary funds due to avoidance of possible expenditures of the regional (local) budget for the elimination of negative consequences in case of refuse from the investment project implementation. The following possible expenditures can be considered:

- Intended for eliminating the consequences of potential accidents, natural disasters;

- Intended for providing material assistance to the victims, costs for the fines payment, and compensation payment;

- Additional costs for purchasing goods and services from other enterprises at higher prices.

\section{Results}

The developed method was tested at the Ukrainian public utility company PUC "Gorvodokanal" of the Sumy City Council (SCC). The analysis shows that PUC "Gorvodokanal" of SCC is unprofitable because of the following factors: existing rates do not correspond to economically justified costs that, as a consequence, leads to the unprofitability and the inability to meet the expenses of the enterprise, as well as to the lack of compensation of the difference in rates from the state budget for services on centralized water supply and water disposal and large amount of receivables.

Consequently, the most important task facing the company management is the effective management of operating costs. First of all, components of the water and wastewater rates were analysed. The analysis shows that the bulk of expenditure is on material costs - $48.3 \%$ (including $39.6 \%$ of costs for electricity); wages fund with charges $-33.5 \%$ and depreciation $-10.0 \%$. Thus, the main reserves for costs reduction include reduction of energy costs.

In order to improve efficiency of energy resources use, two investment projects are proposed: the project on water supply - reconstruction of wells with pumping units of the company (HYDRO - VACUUM); the project on wastewater - re-equipment of KNS-1 with the pumping unit (Flygt) with the control cabinet. Both investment projects are commercially viable, as the net present value, internal rate of return, profitability index and the payback period of these projects meet the criteria of efficiency (NPV $>0$, IRR $<\mathrm{E}, \mathrm{PI}>1, \mathrm{DPP}<6$ years) (Table 2).

In order to reduce operating and capital costs for network maintenance, as well as the loss of drinking water, the project on reconstruction of the steel conduit is proposed. Within the framework of this project, social efficiency is calculated, which shows that with the introduction of this investment project the residents of this neighbourhood can save 791,817.6 UAH per year on the purchase of drinking water by reducing the number of accidents.

The investment project that is proposed for the implementation after fulfilment of all previous projects is the project on reconstruction of the gravity sewer, which allows reducing the costs for major repairs and the risk of environmental disasters. 
Both investment projects are commercially viable, all indicators of economic efficiency of the project correspond to normative values (NPV $>0$, IRR $<$ E, PI $>1, \mathrm{DPP}<10$ years) (Table 2).

Thus, the developed investment program will reduce energy costs and allocations for repairs and maintenance. As a result, the cost of water production will be reduced by 718.8 thousand UAH and the cost of wastewater will be reduced by 266.65 thousand UAH.

To calculate changes in the water supply and wastewater rates, the actual full cost of services is calculated. It is found that as a result of cost reduction the economically feasible water rate will be reduced from $5.651 \mathrm{UAH} / \mathrm{m}^{3}$ to $5.604 \mathrm{UAH} / \mathrm{m}^{3}$, the wastewater rate will be reduced from $3.532 \mathrm{UAH} / \mathrm{m}^{3}$ to $3.512 \mathrm{UAH} / \mathrm{m}^{3}$. Thus, as a result of the proposed measures consumers of services will get social and economic efficiency in the form of the fixed rates at the same level with the possibility of its further reduction, consumers will also get high-quality water delivered without interruption. As a result the budget can be reduced by 615.53 thousand UAH.

Results of the calculations are presented in Table 2.

Table 2. Results of efficiency calculation for the investment program of the Ukrainian Public Utility Company PUC "Gorvodokanal" of SCC

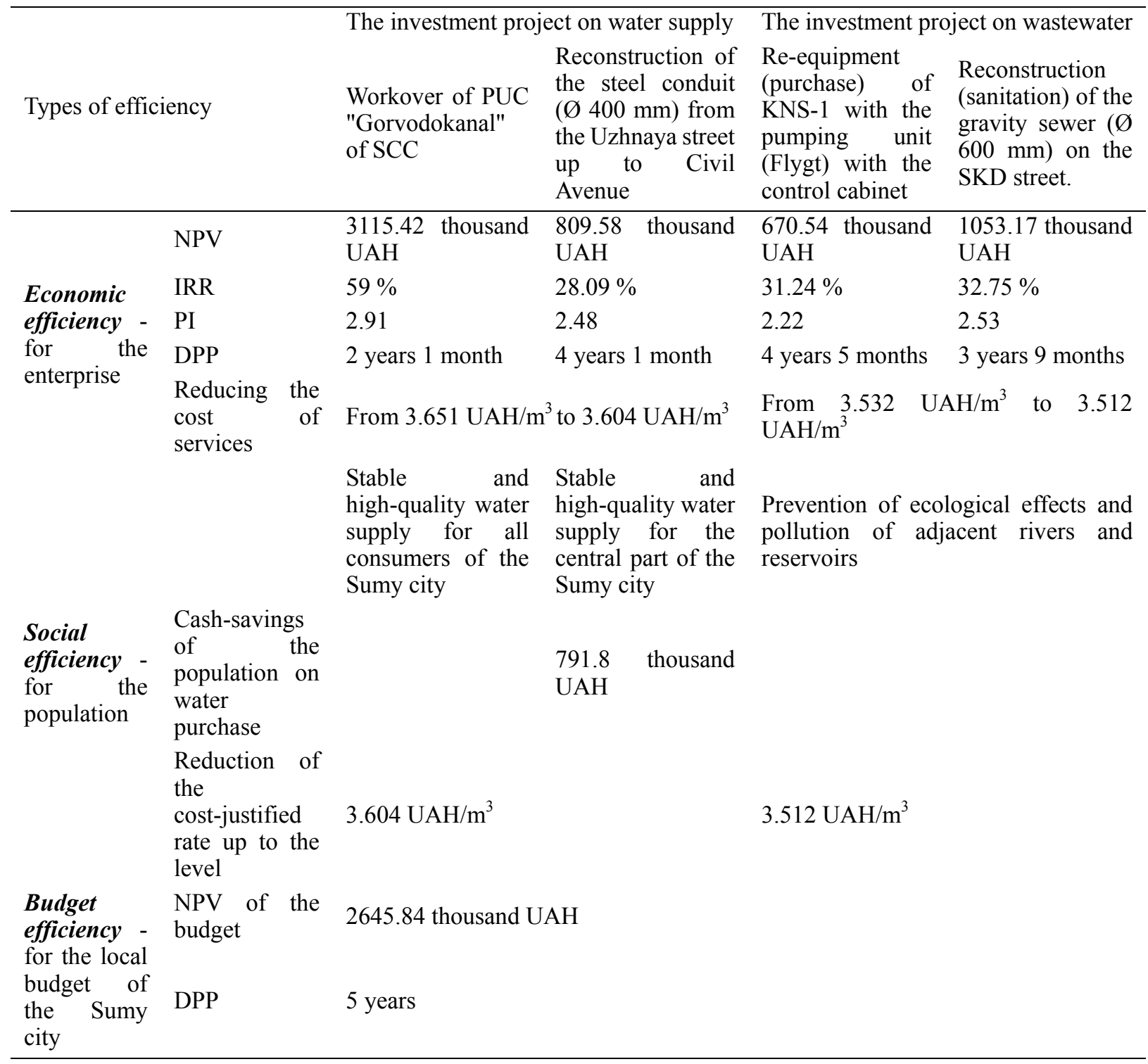




\section{Discussion}

Nowadays, public utility companies occupy a large sector of the Ukrainian economy. The largest volume of services within this sector of national economy is provided by water, heat, hot water supply companies and housing maintenance companies.

The water and waste water services providing enterprises that produce and supply water through the distribution networks are natural local monopolies. The regulation of the company rates for water supply and waste water services in accordance with current legislation on the rate regulation is performed by the National Commission, carrying out the state regulation of public services. The main task, for which the Commission was created, is the transition to incentive rate setting, when an enterprise with the rate for a few years would be interested to pursue a policy of reducing operating costs and increasing the investment component under the current rate.

In this approach the process of the rate formation takes the form of a compromise between the financial needs of the water and waste water services providing enterprises and the effective demand of consumers, taking into account the requirements for quality of services. Long-term calculation of rates dynamics creates certainty in planning cash flows of an enterprise. In turn this reduces the risks of investing and the water and waste water services providing enterprises become interested in reduction of costs and acceleration of the repayment of borrowed funds.

The analysis of rate policy monitoring within various Ukrainian regions shows that in general in Ukraine there is a large amount of cross-subsidization, in which the rate burden is shifted from the public to enterprises and other organizations, and only in certain regions, such as Ternopoil, Lviv, Volyn regions, there is a tendency of convergence of rates for different groups of consumers - the gradual elimination of cross-subsidization system.

However, in recent years in terms of services provided to the population, the growth rate of underfunding is much lower than the actual growth rate of financing. This indicates some positive results of transition of the economic sector to self-financing. The population, in practice, are more disciplined payers, even under significant growth of rates, than the budget in terms of reducing the share of budget financing. Collection of payments of citizens for the water and wastewater services accrued for 2013 by the public utility company PUC "Gorvodokanal" of SCC amounted to $95.3 \%$, including $94.3 \%$ of the population, while funding of benefits and subsidies from the consolidated budget was carried out in the amount of not more than $30 \%$ of the needs.

Current rates for water supply and wastewater services provided to the population do not correspond to the economically justified costs for their production, which, as a consequence, leads to the unprofitability and the inability to carry the costs of the company. This increases the load of the budget - an increase in revenues from the budget to cover the difference in rates for services on centralized water supply and wastewater disposal.

\section{Conclusion}

In this article, the authors examine the theoretical aspects of assessing the investment efficiency of the enterprises providing public services. The authors propose the use of three directions for evaluation of the economic, social and budgetary efficiency.

Social efficiency of the investment project resides in the fact the as a result of modernization and reconstruction of existing production, the cost of services delivered will decrease, and respectively will occur a decrease in the economically justified rates or prices; meanwhile the quality of services provided to the society will also improve. Budget efficiency is caused by the excessive budget funds savings for the provision of public services over the budget investments in improving the economic efficiency of enterprises. Therefore, to determine the efficiency of the production of public services, it is necessary to carry out a comprehensive analysis of the efficiency, taking into account all the elements of service delivery.

The result of the implementation of the developed investment program of the enterprise development will be reduction of the economically justified rates for water and wastewater services, which ultimately will affect all the subjects of the system of water supply and wastewater services. As for the enterprise, this investment program will reduce energy costs and allocations for repair and maintenance. As a result of the measures proposed by the author, consumers of services will get social and economic benefits in the form of reduction of the economically justified rates with a further opportunity to reduce the water and wastewater rates, as well as to get high-quality water provided without interruptions, while the ecological situation in the region will be improved. As for the budget, in the second year after the implementation of the investment program, these changes will cause a decrease in budgetary burden for compensation of public utilities costs to the indigent. 


\section{Acknowledgements}

The article is prepared with the support of the Ministry of science and education of the Russian Federation (project No. 26.1303.2014/K).

\section{References}

Aleshinskaya, N., Vilensky, P., Volkov, V., Granberg, A., Kossov, V., Livshits, N., ..., Shahnazarov, A. (2004). Recommendations for the evaluation of investment projects. Institute of Systems Analysis, Russian Academy of Sciences, Central Economics and Mathematics Institute, RAS. Moscow.

Averina, O., Davydova, V., \& Lushenkova, N. (2012). A comprehensive economic analysis of economic activity: the Textbook. Moscow: KnoRus.

Bagel, N., Lukin, I., Shashkov, T., Chuvilin, D., \& Sharipov, L. (2012). Improvement of the validity level of utility rates on the basis of economic and mathematical modelling. Journal of Economics Issues, 4.

Bakhmutskaya, A., \& Kudryavtseva, T. (2010). The formation of a balanced scorecard efficiency of budget expenditures. Scientific and technical sheets, St. Petersburg State Polytechnic University. Economic sciences, 3(99), 137-146.

Demidenko, D., Babkin, A., \& Kudryavtseva, T. (2010). Optimization of budget spending on quality control of public goods. Scientific and technical bulletin of the St. Petersburg State Polytechnic University. Economic sciences, 6(112), 204-208.

Efimova, Y. (2011). Choice of discount rate to assess the investment projects efficiency among the industrial enterprises. Scientific journal "Proceedings of the Tula State University" Economic and legal sciences, $1,1$.

Egorova, N., Mitrofanov, I., \& Shein, A. (2007). Category: Economy. Economy of housing and communal services. Simulation model of housing and communal enterprises as a tool of analysis of rate-price mechanism. Audit and financial analysis, 6, 160-198.

Government Decree of the Nizhny Novgorod region No. 205 "Process for assessment of budgetary and social efficiency of investment projects (to be implemented) in the Nizhny Novgorod region". (2007, June 27).

Gritsko, M. (2012). Evaluation of the efficiency of municipal services provision (for example, the urban district "Khabarovsk"). Science Journal.

Kasyanenko, T., \& Makhovikov, G. (2009). Investments: Textbook. Moscow: Penguin Books.

Kuporov, Y. (2014a). Features of the analysis of investment projects in imperfect markets. Scientific and technical newsletter C-PbGPU. Economic sciences, 1, 133-138.

Kuporov, Y. (2014b). Evaluation framework for human resources. Economic science and practice. International Scientific Conference, Chita, Young scientist Publishing, 133-139.

Oksogoev, A. (2014). Economic problems of the regions and industry systems. Management mechanisms and utilities infrastructure in the region. Journal of the Problem of the modern economy, 4(40), 327-330

Rodionov, D. G., Rudskaia, I. A., \& Guzikova, L. A. (2014). Innovation potential of regions as a factor of national economy competitiveness. Scientific Economic Journal (Actual Problems of Economics), 8(158), 215-223

Sergeev, I., Veretennikova, I., \& Shekhovtsov, V. (2013). Tutorial and workshop. Investments. Moscow: Publishing Yurait.

Zaborovskaia, O. V., Plotnikova, E. V., \& Sharafanova, E. E. (2014). Assessment of Conditions for Formation and Development of Human Capital in the Regions of the Russian Federation. Asian Social Science, 10(21), 267-274. http://dx.doi.org/10.5539/ass.v10n21p267

\section{Copyrights}

Copyright for this article is retained by the author(s), with first publication rights granted to the journal.

This is an open-access article distributed under the terms and conditions of the Creative Commons Attribution license (http://creativecommons.org/licenses/by/3.0/). 